\title{
'Moderate universalism' in China and the Nordic countries: Reviewing the major challenges in unemployment protection
}

\author{
Kristian Kongshøj \\ Centre for Comparative Welfare Studies (CCWS), \\ Aalborg University \\ Sino-Danish Centre for Education and Research (SDC), \\ Beijing \\ Email: kongshoj@dps.aau.dk
}

\begin{abstract}
Rapid welfare expansion is taking place in China across a range of policy fields. In the Nordic countries, intra-Nordic diversity and significant policy changes are not difficult to identify despite the notion of universal Nordic welfare regimes. This article will bridge these very different worlds of welfare in an effort to classify the Chinese unemployment-protection system with a comparative framework aimed at furthering the emerging Sino-Nordic research dialogue. This research dialogue has gained relevance in recent years with the new official Chinese goal of building a more universal welfare system. Welfare research that includes China from a comparative perspective is still extremely rare. Despite the lofty Chinese goals, many Chinese policy challenges still loom large. These are the rural-urban divide exacerbated by the Chinese household registration system, coverage of unemployment insurance and social assistance, inadequate and declining benefit levels, and, finally, funding issues. As this article will also substantiate, Denmark and Finland are something approaching best cases for illustrating intra-Nordic diversity. As regards the Chinese challenges, it is explained how they can to some extent be understood as the teething troubles of a developmental welfare state, since the Nordic counterparts have faced similar issues during their eras of welfare expansion.
\end{abstract}

Keywords: China, Nordic countries, unemployment, income protection, welfare regimes, Denmark, Finland, social policy 


\section{Introduction}

Market-oriented reforms of the labour market and the emergence of unemployment as a social problem are more than anything else the epicentre of dramatic social change in China in recent decades (Xu, 2012; Lee \& Warner, 2007). The social-policy response to this has been the introduction of both unemployment insurance and social assistance, and there is by now a relatively rich English literature on the development and challenges of these new schemes (for example Liu \& Kongshøj, 2014; Ngok, 2013; Gao, 2013; Lei, 2012; Chan, 2010; Duckett \& Carillo, 2008). This literature will also be drawn on later in this article. However, very little has been done in terms of classifying the Chinese income-protection schemes towards unemployment from a comparative perspective. The first and most basic aim of this article is to engage in this. Dimensions of income protection benefits such as benefit levels, coverage, eligibility, and financing are classic in comparative welfare research (Danforth \& Stephens, 2013), and will also be used to track developments and challenges here in social rights for the unemployed from a comparative perspective. For such comparative enquiries to include China is still a rarity. Even within the broader welfare regime approach, China is curiously enough not always included in the literature on East Asia, although this might in part be a reflection of the fact that there is great deal of social policy devolution in China, which makes it difficult to talk of a nationally coherent welfare state as such. To the extent that China is included, China is mostly seen in light of the predominant East Asian regime traits (Lei Choi, 2013; Lei, 2012; Leung, 2005), which we will return to below.

The Chinese welfare state might still be described as existing in a state of institutional ambiguity, in which several paths of welfare development are still open. Hugh Heclo (1974) was among the first to point to the role of ideas and information in the way policy-makers try to solve problems, which is of course also crucial to understanding the development in China. Interestingly, Chinese policy makers are actively learning from other countries and often engage experts from international organizations such as ILO, UN, and the World Bank (Leung, 2005). As unemployment policy is the focus of this article, it is interesting to note that the Chinese Ministry of Labour reviewed the experiences of more than 40 countries before setting up a system of unemployment insurance. Amidst all these ambiguities and possibilities, this article will track current Chinese policy developments 
and point to some issues faced by income-protection schemes for the unemployed.

A second aim of this article is basically to contrast China, popularly perceived as bogged down by rising inequalities and freshly unleashed market forces, with two other cases popularly perceived as relatively equal societies with all-encompassing welfare states deeply enmeshed in market forces, namely Denmark and Finland. Limited as the comparative literature on China is, analyses of China and nonAsian cases are much rarer. Sino-Nordic comparative research is still almost non-existent. Kettunen et al. (2014) have edited the first SinoNordic welfare anthology, but of the individual contributions, only Hua and Rønning (2014) include a Sino-Nordic comparison of elderly care. There is nothing to be found on unemployment policy. Consequently, our basic comparative aim is narrowed down to a Sino-Nordic framework. This framework is rooted in the welfare-regime literature on Nordic and East Asian welfare regimes. The particular choice of the two cases of Denmark and Finland as the Nordic cases is not only based on welfare regimes but also on a closer scrutiny of the actual labour-market schemes, which we shall expand upon below. This scrutiny reveals how these two cases serve well to capture intraNordic diversity despite the more general notion of Nordic welfare regimes.

The third and final aim of this article is simply to contribute to and to further the emerging Sino-Nordic scholarly dialogue. China is of course an interesting case for Nordic researchers because the global impact of its rise and the rapid development of Chinese social policy, which can serve as a playground for old theories on welfare-state development. However, Chinese interest in Nordic social policy has also been growing, both among scholars and policymakers. Chinese researchers began writing on Nordic welfare states as early as the 1980s, but the Chinese literature grew in earnest in the late 1990s (Zhang, 2013; Lin, 2001). Sweden has dominated that literature as the most well-known example of the universal welfare state. At the same time, in the new millennium, Chinese policymakers have increasingly emphasized the need for more comprehensive welfare, for example, under the slogan of creating the 'harmonious society' under Hu Jintao and Wen Jiabao (Ngok, 2013). In spelling out this vision, the term 'social policy' was used for the first time in official documents in 2006. An idea of building a 'moderate' or 'appropriate' universal welfare system has also been voiced frequently by policymakers and was first promoted by the Chinese Ministry of Civil Affairs (Lei \& Walker, 2014; 
China.org.cn, 2012). As an example of the potential for Sino-Nordic social-policy dialogue, the report 'Constructing a Social Welfare System for All in China' by the Development Research Centre of the Chinese State Council, an official think tank reporting directly to the Chinese State Council, deserves to be mentioned. The report showcases specific Nordic policies several times as it lays out a vision for a more inclusive welfare system. The foundations for the report were laid when the research group behind the report made a trip to Copenhagen and gained input from Danish researchers on '...the experience of European countries and America in building and reforming social welfare systems' (CDRF, 2012, xxviii).

It should be noted that the enquiry in this article will focus on social rights for urban citizens in China. This is because of the household registration system, hukou, that in essence enforces a divided citizenship in China by dividing people into rural and urban citizens with very different sets of social rights, often leaving rural citizens to fend for themselves (Xu, 2012). In rural China, the policy responses towards unemployment are still very fragmented and limited, especially because unemployment there is still regarded as 'hidden' or 'surplus labour', and still not subject to national policy objectives (Murphy \& Tao, 2007). Consequently, there is no official registration of unemployment in rural China. However, as will be explained later, rural citizens have the right to enjoy social assistance.

The hukou system is also essential for understanding the biggest challenge for Chinese social policymaking, namely the 250 million rural-urban migrant workers living in urban areas with rural hukou. They are excluded from urban welfare schemes, despite attempts from the national government in recent years to make urban welfare schemes more inclusive. In this context, it is important to note that rural-urban migrants are still excluded from the new social assistance, the Minimum Living Standard Scheme (MLSS)., which will be explained further below, and that surveys in 2005 and 2010 placed coverage of unemployment insurance among migrant workers at a very low nine to ten per cent (Wong, 2013).

\section{Establishing the comparative framework}

While the exact clustering or grouping of countries, as well as the number of regime ideal-types, is a subject for endless discussion in 
the welfare-regime approach, the notion of a Nordic 'universal' continues to find support (Arts \& Gelissen, 2010). There is a good deal of literature on East Asian welfare regimes, complete with a host of different labels to name them, with those of 'productivist' and 'developmental' being the most popular (Abrahamson, 2011). Another popular label has been that of 'Confucian' welfare regimes, which, as the name suggests, have a strong tacit notion of culture as a driver of welfare-state development, but mostly emphasizes the same characteristics as those we list below in table 1 .

'Universalism' as a concept is quite contested and multi-dimensional (Anttonen et al., 2012), but the same can be said of the labels of 'productivism' or 'developmentalism'. However, the core of both labels is that social policy in these regimes is subordinate to economic policy (Choi, 2013; Holliday, 2005). Yet productivism in social policy is certainly not isolated to one specific welfare regime. It has often been noted that productivism has been a very strong characteristic of the Nordic welfare states (Andersson, 2009). Esping-Andersen (1999), for example, wrote that 'Scandinavian welfare and employment policy has always been couched in terms of "productivism", that is maximizing the productive potential of the citizenry' (p. 80). Trying to achieve policy for markets rather than against markets is not specific to any welfare regime. However, the degree to which the welfare state shapes market forces varies across regimes. A universal welfare regime alters the workings of market forces more than any other to promote social citizenship, at least in the ideal-typical world. Here we find a core motivation for contrasting China with Nordic countries.

We can continue to spell out this difference between these two welfare regimes even further. Even if the labels traditionally used to describe both Nordic and East Asian welfare states are complex and contested, particularly as principles for social policy, a set of welfare-regime characteristics spanning both outputs and outcomes have become connected to these labels in the welfare-regime approach. First, Esping-Andersen's (1990) regime typology was based on decommodification and welfare stratification. Secondly, there is, as mentioned, the question of the different policy principles that govern social rights. This is where labels such as 'universal' or 'residual' more correctly come into play. Thirdly, as the research tradition increasingly emphasizes the diversity within welfare provision, the welfare mix becomes important. Finally, one can also consider the degree to which social policy is subordinate to market forces and economic 
goals, a question raised by the literature on East Asian welfare regimes.

Taking the dimensions of welfare regimes mentioned here into consideration, we can summarize the differences between universal and productivist welfare regimes in table 1 :

Table 1: Dimensions of universal and productivist welfare regimes

\begin{tabular}{lccccc} 
& $\begin{array}{c}\text { Social policy } \\
\text { in relation to } \\
\text { market forces }\end{array}$ & $\begin{array}{c}\text { Social } \\
\text { rights }\end{array}$ & $\begin{array}{c}\text { Degree of } \\
\text { decommodifi- } \\
\text { cation }\end{array}$ & $\begin{array}{c}\text { Degree of } \\
\text { welfare } \\
\text { stratification }\end{array}$ & $\begin{array}{c}\text { Welfare mix: } \\
\text { Individual vs. family } \\
\text { \& market vs. state }\end{array}$ \\
\hline Universal & $\begin{array}{c}\text { Least } \\
\text { subordinate }\end{array}$ & $\begin{array}{c}\text { Extensive, } \\
\text { linked to } \\
\text { citizenship }\end{array}$ & Highest & Lowest & Individual-state \\
& $\begin{array}{c}\text { Most } \\
\text { subordinate }\end{array}$ & $\begin{array}{c}\text { Minimal, } \\
\text { linked to } \\
\text { productive } \\
\text { activity }\end{array}$ & Lowest & Highest & Family-market \\
\hline
\end{tabular}

Assessment based on Anttonen et al. (2012), Aspalter (2011), Lee \& Ku (2007), Holliday (2000).

The purpose of table 1 is mainly to illustrate how these two idealtypical welfare regimes are very nearly polar opposites on all dimensions, though it would be wrong to conclude that the three classic regimes are opposites in any way. All of these five dimensions are, of course, very closely linked. Extensive, citizenship-based rights spill over into high decommodification, low stratification, and a more prominent role of the state in the overall welfare mix.

With this framework in mind, we can leave the ideal-typical world behind. While it is of course trivial to say that there is no truly universal welfare regime in this world, in the Nordic family it seems to be particularly true of Finland. Here we find our motivation for including Denmark and Finland as representatives of the diversity one can actually find within the Nordic cluster of welfare regimes. While the many studies within the welfare regime industry consistently group Denmark, Norway, and Sweden together, Finland does not always seem to fit too well. For example, in the 11 studies reviewed by Arts and Gelissen (2010), Finland is covered by ten, only five of which 
actually classify Finland as a 'universal' welfare regime. Indeed, even in Esping-Andersen's (1990) original study on the three worlds of welfare, Finland's decommodification score ${ }^{1}$ for unemployment insurance lagged somewhat behind the three other countries. In Scruggs and Allan's (2006) replication of the decommodification index for the year 2000, only Belgium, Denmark, the Netherlands, Norway, and Sweden score above ten, while Finland scores 8.1 for unemployment insurance. Replacement rates are a case in point of these differences; Danish unemployment insurance is the least earnings-related of the four Nordic schemes (constituting instead something approaching a relatively generous flat-rate universalism) while the Finnish scheme is the most earnings-related ${ }^{2}$ (OECD, 2010). It should be noted that the question of flat-rate versus earnings-related benefits is a long-standing discussion in the literature on universalism (see for example Anttonen et al., 2012). The argument for earningsrelated benefits as being more universal is that these more adequately guarantee income protection for a larger share of the population and prevent the crowding-in of private insurance. Regardless of this discussion, Denmark and Finland are Nordic opposites in this respect. In unemployment protection, Denmark, Finland, and Sweden have all retained their state-subsidized, voluntary unemployment-insurance funds administered by trade unions (also known as the 'Ghent model', named after the Belgian city in which the system originated). Norway was actually the first Nordic country to adopt this system in 1906, but switched to compulsory insurance in 1938 (Edling, 2006).

This also means that unemployment policies and labour markets in general are very different in Finland and Denmark. For example, while the concept of flexicurity has been seen as a strong Danish trait, the data of Berglund and Madsen (2009) from the beginning of the millennium suggests that Finland has the weakest flexicurity profile within the Nordic family. In this case, this is measured by the following indicators: 1) benefit spending per unemployed, 2) active labourmarket policy spending as percentage of GDP, 3) employmentprotection legislation (index defined by OECD), and 4) the share of the workforce engaged in life-long learning measures.

\footnotetext{
${ }^{1}$ The decommodification score is measured by replacement rates, duration, eligibility, coverage rate, and waiting days.

${ }^{2}$ Measured simply as the difference between net replacement rates for 150 per cent of average wage and 67per cent of average wage (all household types included).
} 
Unemployment insurance is also a good example of how real-world policies may often be far removed from ideal-typical universalism since it requires insurance participation; however, the Nordic experience is also a good illustration of how policy institutions can incrementally be reformed towards a relatively high degree of universalism (compared with other countries) by increasing coverage, minimum benefit levels or state-financing (Goul Andersen, 2012; Edling, 2006), which we shall also discuss later. From this perspective, universalism is seen as a continuum of degrees rather than either/or.

In this article we shall also consider social-assistance-like schemes, and here Gough's (2001) oft-cited study of social-assistance typologies places Denmark, Finland, and Sweden together in the cluster characterized by 'average extent, average inclusion/exclusion and generous benefits' (p. 169). The more recent data of Kuivalainen and Nelson (2012) suggests that although the Nordic countries are still relatively similar in respect of replacement rates, they are no longer particularly generous in this respect. Pfeifer (2012) tries to include both the insured and non-insured in her study which includes four main indicators. ${ }^{3}$ Of the four resulting clusters, Denmark and the Netherlands end up together in 'extensive protection-functioning labor market', while Finland, Sweden, and four other countries are labelled as 'targeted protection-insider/outsider labor market' (p. 20).

The discussion above pinpoints some arguments why Denmark and Finland are something approaching best cases when one wishes to capture intra-Nordic diversity (both from the approaches of general welfare typologies and typologies of unemployment protection). Now we are faced with the question of how China fares in relation to these typologies.

\section{Unemployment policies in a Sino-Nordic perspective}

A thorough historical account of the post-Maoist labour market reforms and the incremental commodification of Chinese labour will not be engaged here (see for example Xu, 2012; Warner \& Lee, 2007). A clear trend in unemployment policy is the emergence of a two-tier

\footnotetext{
${ }^{3}$ The four indicators being generosity, spending (per recipient and per cent of GDP), recipiency rates, and unemployment rates
} 
system, one being unemployment insurance, and the other the Minimum Living Standard Scheme (MLSS). The Chinese unemployment-insurance scheme was formally acknowledged in 1999, but it has precursors dating back to a very important 1986 labour-market reform, in which employer discretion to lay off workers was recognized and a so-called job-waiting insurance was set up for a limited group of state-sector employees (Vodopivec \& Hahn, 2008; Webber \& Ying, 2007).

The MLSS developed in successive phases from the early 1990s and onward. Social researchers initially promoted the idea of a universal, social-assistance-like scheme following the collapse of the old 'iron rice bowl' (Guan \& Xu, 2011). An urban MLSS was pioneered in Shanghai, while a county in Shaanxi province pioneered a rural counterpart, but the development and expansion of the rural MLSS remained sluggish, not least because the central government did not prioritize it. The MLSS was made a national policy in 2007. This also means that the MLSS is the most important example of a social right being expanded to both rural and urban China. However, since it is not available for people without local hukou, many Chinese citizens, particularly the rural-urban migrants, are still excluded from the scheme. It should be noted that residual social relief in China goes further back than the new MLSS. Importantly, the so-called five guarantees (originally food, fuel, clothing, education, and burial, but also later expanded to include housing assistance and medical care) have been in place in rural China since the days of the planned economy. In urban China, residual relief was mainly directed at people afflicted by the so-called three no's (no work, no family, and no independent means of living) (Leung, 2005).

Turning to comparative policy variations between the countries in question here, table 2 reveals the main differences regarding generosity, eligibility, and duration of unemployment insurance (UI). One important distinction is that the Chinese $\mathrm{UI}$ scheme is not earnings-related, but flat-rate and defined by local governments, with the requirement that it must be above the minimum level of living, but below minimum wage. These two boundaries are also locally defined, however, so this is another example of the high level of policy discretion of local government. 
Table 2: Unemployment insurance in China, Denmark and Finland

\begin{tabular}{|c|c|c|c|}
\hline & China & Denmark & Finland \\
\hline Generosity & $\begin{array}{l}\text { Not earnings- } \\
\text { related: Locally } \\
\text { defined, but must } \\
\text { be above locally } \\
\text { defined minimum } \\
\text { level of living and } \\
\text { below local } \\
\text { minimum wage. } \\
2011 \text { average } \\
\text { net replacement } \\
\text { rate: } 23 \%\end{array}$ & $\begin{array}{l}90 \% \text { of previous } \\
\text { wage, but with a } \\
\text { low ceiling at } \\
2300 \text { EUR/month } \\
\text { (2012). De facto a } \\
\text { flat-rate benefit } \\
\text { for most workers. }\end{array}$ & $\begin{array}{l}\text { Basic allowance } \\
\text { at } 675 \\
\text { EUR/month } \\
(2012)+45 \% \text { of } \\
\text { previous wage } \\
\text { above basic } \\
\text { allowance up to } \\
3290 \text { EUR (2012). } \\
\text { For any remaining } \\
\text { wage level above } \\
\text { this, the rate is } \\
\text { reduced to } 20 \% \text {. } \\
\text { These } \\
\text { replacement rates } \\
\text { can be raised to } \\
57.5 \% \text { / } 35 \% \\
\text { (initial } 100-200 \\
\text { days) or } 65 \% / \\
37.5 \% \text { if special } \\
\text { requirements are } \\
\text { met. }\end{array}$ \\
\hline Duration & $\begin{array}{l}1-2 \quad \text { years } \\
\text { dependent on } \\
\text { contribution } \\
\text { period: Less than } \\
5 \text { years = } 1 \text { year } \\
\text { duration, more } \\
\text { than } 10 \text { years = } 2 \\
\text { year duration. }\end{array}$ & $\begin{array}{l}2 \text { years (within } \\
\text { the last } 3 \text { years) }\end{array}$ & $\begin{array}{l}2 \text { years }(500 \\
\text { benefit days, } 5 \\
\text { days per week })\end{array}$ \\
\hline Eligibility & $\begin{array}{l}\text { Contribution } \\
\text { requirement of } 1 \\
\text { year. }\end{array}$ & $\begin{array}{l}\text { Work } \\
\text { requirement: } 52 \\
\text { weeks of full time } \\
\text { work (37 hours) } \\
\text { within } 3 \text { years. } \\
\text { Membership: } 1 \\
\text { year. }\end{array}$ & 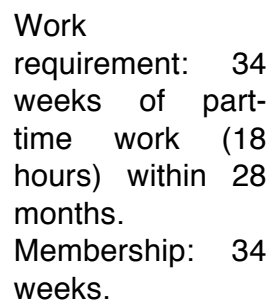 \\
\hline
\end{tabular}

Sources: National Bureau of Statistics of China (2013); The Federation of Unemployment Funds in Finland (2012); The National Labour Market Authority (2012); Vodopivec \& Hahn (2008) 
However, formally earnings-related benefits can also be made de facto flat-rate if coupled with low benefit ceilings. This is the case in Denmark, where the benefit ceiling has become quite low relative to most working wages (Goul Andersen, 2011a). The difference is, of course, the level of the benefits. While the Danish benefit still constitutes a somewhat generous flat-rate universalism, the average net replacement rate in urban China has dropped from 33 per cent to 23 per cent of the average urban working wage in 2001-2011. Benefit levels have increased significantly in absolute terms, but have simply not been kept level with the rapidly rising wages.

Figure 1: Gross replacement rates of unemployment insurance in Denmark and Finland (2012)

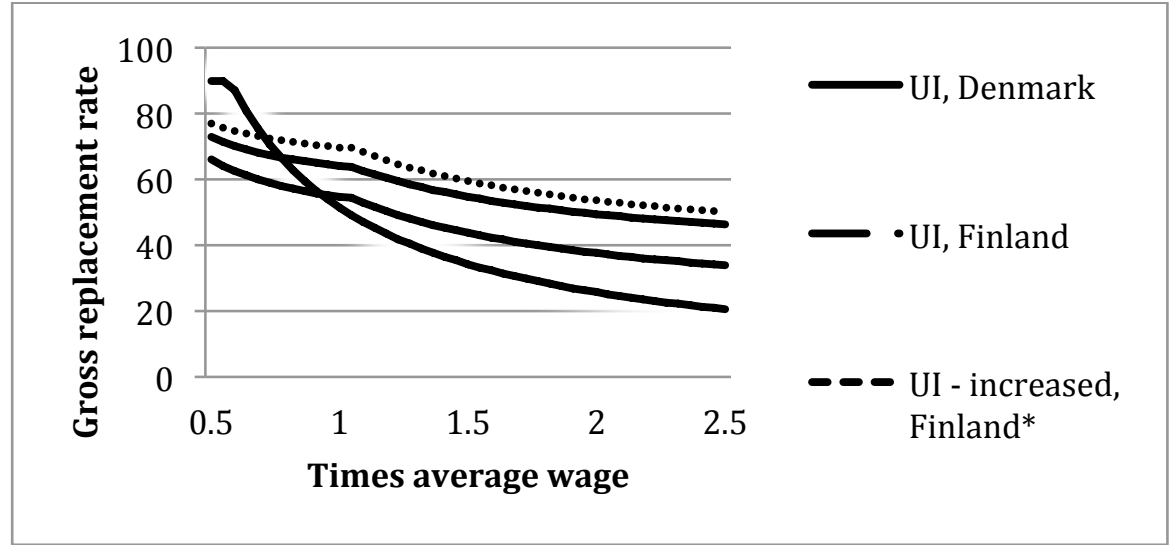

Note: Average wages are based on the assumption that the difference in average wage between Denmark and Finland in 2012 was the same as in 2011 (38\% higher in Denmark according to UNECE)

* Increased unemployment insurance in Finland: Available during the first 20100 workdays of unemployment, depending on work and membership history (20 days $=3$ years of work; 100 days $=20$ years of work, membership for five years)

** Unemployment insurance with transition assistance: Available during participation in certain active measures (maximum is 200 work days)

Sources: The Federation of Unemployment Funds in Finland (2012); The National Labour Market Authority (2012); UNECE Statistical Database (2013); Statistics Denmark (2013)

As mentioned earlier, the Danish scheme might be understood as somewhat generous flat-rate universalism while the Finnish counterpart is much more earnings-related, which is exactly what 
figure 1 illustrates (albeit as gross replacement rates). This is a reflection of the fact that the Danish benefit ceiling is quite low (and affects almost all incomes), while the Finnish scheme has no ceiling, which is quite unusual. Because of the high replacement rate of 90 per cent below the ceiling, the Danish scheme is relatively generous for low incomes (Nososco, 2012), which is also shown in figure 1. This is an example of an area where the Finnish welfare regime can be understood as a hybrid between universalism and labour-market status-maintenance (Clasen et al., 2001). However, if an unemployed is eligible for 'increased' UI in Finland (available the first 150 days of unemployment for unemployed with long employment histories) or UI with 'transition assistance' (where specific plans for re-employment are drawn up with the aid of ALMP measures), the Finnish scheme becomes more generous for middle and lower incomes compared with its Danish counterpart. If we turn to eligibility, the Danish scheme appears to be the least 'generous'. Both membership and work requirements are stricter than in China and Finland. In Denmark, the work requirement entails 1924 hours of work (within the last three years) while it in Finland is 612 hours of work (within the last 28 months).

Instead of a fund membership requirement, China has a contribution requirement. Duration periods are somewhat similar, with a notable difference in the way that duration in China is graded according to contribution time, ensuring that only a 10-year contribution period gives access to the full two-year duration period. In all three countries, it is of course also required that one is actually available for vacant positions and actively looking for a job, but the specific job-availability requirements may vary. Looking at Venn's (2012) indexes of job search and availability requirements, as well as the sanctions linked to these, it appears that overall job-availability requirements are far stronger in Denmark (only Germany and Norway are stricter among the 36 countries examined), while Finland is among the most lenient countries. Sanctions for breaching the job-availability requirements are somewhat stronger in Finland.

If the insured unemployed face much lower benefit levels in China, the differences are even more pronounced for the uninsured. In 2010, the average recipient of the urban MLSS was granted $162 \mathrm{RMB} /$ month, or a mere 5.3 per cent of the average wage (gross replacement rate) in 
urban China $^{4}$ (National Bureau of Statistics of China, 2013; Ministry of Civil Affairs, 2013). In 2008 in Denmark and Finland, uninsured unemployed would get 41 per cent and 38 per cent, respectively, of the disposable income of the average worker (net compensation rate) (Nososco, 2012). The MLSS is income-tested, and a recipient is formally entitled to get the difference between his current income and the local MLSS threshold (also the so-called minimum level of living, which defines the lower threshold of UI benefits). This MLSS threshold has been lagging somewhat behind disposable incomes (Gao, 2013). From 1999 to 2009, the average urban threshold dropped from 31 per cent to 16 per cent of average per capita disposable income (Lei, 2012).

The Finnish and Danish counterparts for the uninsured are also means-tested like most social-assistance schemes. While Nordic social-assistance schemes have often been classified as having relatively generous benefit levels, the means tests are quite strict. In Denmark, about 75 per cent of the uninsured employed will not be able to receive social assistance if they lose their job because of strict negative selectivity regarding personal assets and spousal income (The Economic Council of the Labour Movement, 2012). In Finland, it should be noted that two types of flat-rate unemployment assistance exist. The Basic Unemployment Allowance is available for those who meet the formal work requirements (these are the same as for the earnings-related UI component, see table 2), while the Labour Market Support is paid to those who have exhausted their UI benefit duration or do not meet the employment criteria (Kela, 2012; Ervasti, 2002). The Labour Market Support is means-tested and graded according to personal and spousal income, while the Basic Unemployment Allowance is only graded to incidental or part-time income while unemployed.

However, the means testing of the Nordic schemes pales in comparison with their Chinese counterpart. Often, eligibility becomes

\footnotetext{
${ }^{4}$ It should be noted that the MLSS is granted on household basis and that the income test is also based on average income in the household (Ngok et al., 2011). For example, in a one-income household with a wage of 500 $\mathrm{RMB} /$ month, the average income is $250 \mathrm{RMB}$ if there are two household members. If the MLSS-line is at $300 \mathrm{RMB}$, that means that each household member is granted $300-250=50 \mathrm{RMB} /$ month (or $2 \times 50=100 \mathrm{RMB}$ for the household). On average there are two household members in households enjoying the MLSS (and each member on average gets the 5 per cent replacement rate mentioned above)
} 
extremely strict in implementation, even if the scheme formally covers everyone below local poverty thresholds. In practice, able-bodied poor with the ability to work are often excluded, and possession of material housing goods (electric appliances such as a refrigerator or motorized vehicles, for example) or even pets can be included in local practices of determining eligibility (Gao, 2013; Lei, 2012; Solinger, 2011). Local administrations often turn down applications on the basis of a general perception of welfare dependency or 'raising lazy people'. Consequently, coverage is still much lower than should formally be the case.

That the MLSS scheme might be able to create poverty traps or perverse incentives is certainly possible, even if the cash-benefit level itself is quite meagre and declining in relation to replacement levels. This is due to the fact that a range of extra entitlements often accompanies the status of being a beneficiary, such as health, housing or education. For example, recipients in Guangzhou in 2010 could get significant benefit increases if they were eligible for an extra educational subsidy, elderly-couple subsidy, 'Three-No' subsidy, or health subsidy. Other entitlements included additional housing subsidies, complete exemption for educational costs, free access to medical insurance, vouchers for daily necessities, and more (Lei, 2012). That the baseline for the cash benefit is only part of the story regarding social assistance is very common, but it is particularly true in the Chinese case. Still, the stigmatizing effect of the local means test is also part of the story, just as the status of being a recipient itself can be stigmatizing and shameful. This is exacerbated by policies such as the 'public review', formally defined as a tool to avoid fraud, where information on applicants is publicly available on local noticeboards. Interviews with the poor have also revealed that many simply refrain from applying for these reasons, or that recipients avoid socializing with others owing to feelings of shame (Liu, 2011; Solinger, 2011).

\section{Resolving some of the teething troubles of a developmental welfare state?}

This account of Chinese unemployment policy has touched upon some of the developmental obstacles. One major challenge is the low coverage of the various schemes. It is difficult to assess the number of potential beneficiaries of the MLSS, though, as mentioned, large 
numbers of Chinese seem to refrain from applying for the MLSS. On the other hand, the number of urban beneficiaries rose sharply from 3.2 million in 2000 to 22.5 million in 2003, and has since been stable. Owing to the recent expansion of the rural MLSS, the number of recipients in China jumped from 16 million in 2006 to nearly 50 million in 2009 (Zhang, 2012). The coverage of UI, however, varied between a mere 32-57 per cent of the registered unemployed in the years 2000-2006 (CDRF, 2012), and then one has to take into account that real unemployment is several times higher. Outside of unemployment policies, policy efforts have expanded health care coverage dramatically and to a lesser extent also pension coverage (National Bureau of Statistics of China, 2012; CDRF, 2012; Manning, 2011). This is mainly a result of new schemes such as the Rural Cooperative Medical System, the new rural pension insurance and pension insurance for hitherto uninsured and unemployed urban workers. Of course, it cannot be taken for granted that a similar expansion of coverage will take place within unemployment. Recent developments such as gradually channelling the previously separately registered 'laid-off' ( xiagang) workers into registered unemployment, and also allowing rural migrants to register as unemployed have great potential to increase the match between real unemployment and registered unemployment.

These problems are not entirely unlike the situation in previously developing welfare states, which would be the case if, for example, we take a historical look at the Nordic countries. In 1913, only about a fifth of Norwegian industrial workers were covered by unemployment fund membership (Edling, 2006). The absolute number of fund members was even lower in Finland, but much higher in Denmark. Coverage of unemployment insurance in China, which has fluctuated around 40-45 per cent of the urban employed in the new millennium, is very like the situation in Denmark and Sweden in 1960 (CDRF, 2012; Edling, 2006). The same goes for the low replacement rates of unemployment insurance and the MLSS. In Denmark, for example, the replacement rate for an average worker was close to 35 per cent before a 1967 reform which doubled the benefit ceiling and the replacement rate jumped to 70 per cent (Jørgensen, 2007).

Unemployment insurance and pensions are also bogged down by a large number of local funds and consequently low-risk pooling, a problem also faced by the pension system (CDRF, 2012). The unemployment funds also operate at city or county level, or even at city district level in some cases (Duckett \& Hussain, 2008). However, 
fragmented systems of numerous funds, leading to big variations regarding fund surplus or deficit (and therefore also variations in fund contributions and benefits) were also common problems in the infancy of unemployment insurance in the Nordic countries before the state assumed marginal responsibility (Jørgensen, 2007; Edling, 2006).

A possible solution to the issue of fragmented Chinese unemployment funds and declining benefit replacement rates is tied to the financing of the unemployment funds. In Denmark, a reform in 1958 replaced a system where contributions varied according to unemployment levels across a range of small funds with one where state reimbursements were tied to unemployment levels (Jørgensen, 2007). In 1967, the state assumed full financial responsibility, and all unemployed began paying fixed contributions. In the Nordic countries, increased state funding made member financing minimal in the 1970s and 1980s at around five to ten per cent in all the Nordic countries when it was at the lowest (Torp, 1999). Subtle contribution reforms (in combination with non-decisions to lower contributions in accordance with falling unemployment) have led to increased member financing in Denmark in recent decades, however (Goul Andersen, 2011b). By 2008, the Danish government even made small profits from the UI scheme.

In general, strongly fragmented welfare systems were also a Nordic experience, despite the fact that these countries were much smaller. Before the first national social-insurance laws in the late nineteenth century, large local disparities could be observed. In pensions, for example, municipalities set up their own insurance schemes, and benefit levels varied widely between rural and urban areas even as national pension schemes had been adopted (Petersen \& Åmark, 2006). Such disparities were most pronounced in Finland, the Nordic latecomer of welfare-state development, which continues to exhibit the strongest regional differences with respect to socio-economic conditions (Pelkonen, 2008).

Numerous other problems facing current Chinese social policymaking could be mentioned, but coverage, benefit levels, and funding constitute the major issues. The aforementioned China Development Research Foundation (2012) dedicates half of its major report Constructing a Welfare System for All to all these issues. Similarly, China's $12^{\text {th }}$ Five-Year Plan (2011-2015) lays out, among other things, a clear vision for increasing coverage of the existing schemes and remedying the rural-urban divide (Lei \& Walker, 2014; CDRF, 2012). 
The awareness of these problems is clearly there, but it remains to be seen how they will be handled.

\section{Conclusion}

While some policy fields such as health and pension insurance in China have seen some significant improvements in coverage and financing (Ngok, 2013), this article has focused on the still significant challenges of income protection for the urban unemployed. Here, the notion of 'moderate universalism' is still detached from reality, and little improvement has been made. In addition, national-level policy towards rural citizens still needs to be developed. Problems with fragmented funding and low-risk pooling persist in China. As regards the Nordic country cases, it has been emphasized that the 'Nordic model' includes a great deal of intra-Nordic diversity at the policy level. Among the Nordic countries, the Danish unemployment-protection scheme is arguably the most universal, and the Finnish scheme is the least so.

However, the common Nordic experience has been that it certainly is possible to universalize unemployment insurance by letting the state assume the marginal risk of unemployment and increasing tax financing, even if such a benefit is formally far from being universal (Goul Andersen, 2012). Fragmented funds with low-risk pooling, low benefits, and financing problems were also pronounced in the Nordic countries (Edling, 2006). At the same time, however, the Nordic Ghent model of unemployment insurance (which does not apply to Norway) has also in recent decades seen some trends of retrenchment or deuniversalization with declining benefit levels, increasing member financing, and declining coverage (Goul Andersen, 2012; Sjöberg, 2011; Ervasti, 2002; Torp, 1999).

Chinese benefit levels, as they have been examined here within unemployment insurance and Minimum Living Standard Scheme (MLSS), have been lagging behind the general income development and are very far from being able to secure adequate livelihoods for citizens facing social risks. Yet some improvements on these issues should not be neglected. In 2007, the MLSS was expanded to rural China. Urban-rural Chinese migrants are now formally being recognized as part of the urban work force, and can for example register as unemployed, even if problems in enforcing their rights still 
exist. The problem of decreasing replacement levels within unemployment and the MLSS remains to be dealt with, however, and so do the risk-pooling and financing issues within the unemploymentinsurance scheme.

As we have also seen, however, the various problems can be understood to constitute some of the expected teething troubles of a developmental welfare state. Our in-depth analysis of unemployment policies revealed how the Chinese problems in some respects are somewhat similar to historical problems in the Nordic universal welfare states in the 1950s and 1960s. Yet the Chinese future is not shaped by irreversible and steadily progressing welfare development locked in on any particular path of convergence with the Nordic countries. China is concerned first and foremost with putting out the immediate fires of its emerging social-insurance model (Liu \& Kongshøj, 2014; Ngok, 2013). However, both Chinese policymakers and particularly researchers are looking to the Nordic countries to some degree, even if Chinese perceptions of the 'Nordic model' are marked by ambivalence about the desirability and feasibility of encompassing welfare (Zhang, 2013; Lin, 2001). The comparative policy analysis of this article has tried to expand this dialogue and to add some nuances about both the Chinese and Nordic cases.

\section{References}

Abrahamson, P. (2011), The welfare modelling business revisited: the case of East Asian welfare regimes. In G. Hwang (Ed.), New welfare states in East Asia. Global challenges and restructuring (pp. 15-34). Cheltenham: Edward Elgar.

Andersson, J. (2009). Nordic nostalgia and Nordic light: the Swedish model as utopia 1930-2007. Scandinavian Journal of History, 34(3), 229-245.

Anttonen, A. , Häikiö, L. Stefánsson, K. \& Sipilä, J (2012). Universalism and the challenge of diversity. In A. Anttonen, L. Häikiö \& K. Stefánsson (Eds.), Welfare state, universalism and diversity (pp. 1-15). Cheltenham: Edward Elgar.

Arts, W. \& Gelissen, J. (2010). Models of the welfare state. In F. G. Castles, S. Leibfried, J. Lewis, H. Obinger \& C. Pierson (Eds.), The Oxford handbook of the welfare state (pp. 569-585). Oxford: Oxford University Press. 
Aspalter, C. (2011). The development of ideal-typical welfare regime theory. International Social Work, 54(6), 735-750.

Berglund, T. \& Madsen, P. K. (2009). Nordic labour market and welfare systems from a flexicurity perspective. In T. Berglund, S. Aho, P.K. Madsen, I. Virjo, B. Furåker, S. Rasmussen \& K. Nergaard (eds.), Labor Market Mobility in Nordic Welfare States (pp. 37-60). Copenhagen: Nordic Council of Ministers.

Chan, C. K. (2010). Re-thinking the incrementalist thesis in China: A reflection on the development of the minimum standard of living scheme in urban and rural areas. Journal of social policy, 39(4), 627-645.

Chan, C. K. ; Ngok, K. L. \& Philips, D. (2008). Social policy in China. Bristol: The Policy Press.

Chau, R. C. M. \& Yu, W. K. (2005). Is welfare unAsian? In A. Walker \& C. Wong (Eds.), East Asian welfare regimes in transition. From Confucianism to Globalization (pp. 21-48). Bristol: The Policy Press.

CDRF (China Development Research Foundation). (2012). Constructing a social welfare system for all in China. Abingdon, UK: Routledge

China.org.cn (2012). The progress made in the field of basic livelihood security in China since the 16th CPC National Congress. Retrieved March 17, 2012, from http://www.china.org.cn/china/20129/20/content_26581726.htm

Choi, Y. J. (2013). Developmentalism and productivism in East Asian welfare debates. In M. Izuhara (Ed.). Handbook on East Asian social policy. Cheltenham: Edward Elgar.

Clasen, J., Kvist, J. \& Oorschot, W. (2001). On condition of work: increasing work requirements in unemployment compensation schemes. In $\mathrm{M}$. Kautto, J. Fritzell, B. Hvinden \& H. Uusitalo (Eds.), Nordic welfare states in the European context (pp. 161-185). London: Routledge.

Danforth, B. \& Stephens, J.D. (2013). Measuring social citizenship: achievements and future challenges. Journal of European Public Policy, 20(9), 1285-1298.

Duckett, J. \& Carillo, B. (2011). China's changing welfare mix: introducing the local perspective. In B. Carrillo and J. Duckett (Eds.), China's changing welfare mix (pp. 1-19). Abingdon, UK: Routledge.

Duckett, J. \& Hussain, A. (2008). Tackling unemployment in China: state capacity and governance issues. The Pacific Review, 21(2), 211-229. 
The Economic Council of the Labour Movement (2012). Hver ottende dansker kan ikke få en krone, hvis de mister arbejdet [Every eighth Dane cannot get a krone if they lose their job]. Copenhagen: The Economic Council of the Labour Movement.

Edling, N. (2006). Limited universalism: unemployment insurance in Northern Europe1900-2000. In N. F. Christensen, K. Petersen, N. Edling \& P. Haave (Eds.), The Nordic model of welfare. A historical reappraisal (pp. 99-144). Copenhagen: Museum Tusculanum Press.

Ervasti, H. (2002). Unemployment and unemployment policy in Finland. In J. G. Andersen, J. Clasen, W. Oorschot \& K. Halvorsen (Eds.), Europe's new state of welfare. Unemployment, employment policies and citizenship. Bristol: The Policy Press.

Esping-Andersen, G. (1990). The three worlds of welfare capitalism. Cambridge: Polity Press.

Esping-Andersen, G. (1999). Social Foundations of Postindustrial Economies. Oxford: Oxford University Press.

Gao, Q. (2013). Public assistance and poverty reduction: the case of Shanghai. Global Social Policy, 13(2), 193-215.

Gough, I. (2001). Social assistance regimes: a cluster analysis. Journal of European Social Policy, 11(2), 165-170.

Goul Andersen, J. (2011a). Denmark - ambiguous modernisation of an inclusive unemployment protection system. In J. Clasen and D. Clegg (Eds.), Regulating the risk of unemployment. National adaptations to post-industrial labour markets in Europe. Oxford: Oxford University Press.

Goul Andersen, J. (2011b). Activation of social and labor market policies in the Nordic Countries, 1990-2010. CCWS Working Article no. 2011-71.

Goul Andersen, J. (2012). Universalization and de-universalization of unemployment protection in Denmark and Sweden. In A. Anttonen, L. Häikiö \& K. Stefánsson (Eds.), Welfare state, universalism and diversity (pp. 162-186). Cheltenham: Edward Elgar.

The Federation of Unemployment Funds in Finland. (2012). Earnings-related allowance. Retrieved July 15, 2012, from http://www.tyj.fi/default.asp?id=92

Guan, X. \& Xu, B. (2011). Central-local relations in social policy and the development of urban and rural social assistance programmes. In B. 
Carrillo \& J. Duckett (Eds.), China's changing welfare mix (pp. 20-35). Abingdon, UK: Routledge.

Heclo, H. (1974). Modern social policies in Britain and Sweden: From relief to income maintenance. New Haven: Yale University Press.

Holliday, I. (2005), East Asian social Policy in the wake of the financial crisis: Farewell to productivism? Policy and Politics, 33(1), 45-62.

Holliday, I. (2000), Productivist welfare capitalism: Social policy in East Asia. Political Studies, 48(4), 706-723.

Hua, F. \& Rønning, Rolf (2014). Status, challenges and innovative solutions for elderly care in China and the Nordic countries. In P. Kettunen, S. Kuhnle \& R. Yuan (Eds.), Reshaping welfare institutions and policies China and the Nordic Countries. Helsinki: NordWel.

Jørgensen, H. (2007). 100 års ledighed [100 years of unemployment]. In J. H. Pedersen \& A. Huulgaard (Eds.), Arbejdsløshedsforsikringsloven 1907-2007. Udvikling og perspektiver [Unemployment-insurance law 1907-2007: development and perspectives] (pp. 147-180). Copenhagen: Arbejdsdirektoratet.

Kela (The Social Insurance Institution of Finland). (2012): Unemployment. Retrieved July 12, 2012, from http://www.kela.fi/in/internet/english.nsf/NET/081101150015EH?Open Document

Kettunen, P., Kuhnle, S., \& Yuan, R. (2014). The development and diffusion of welfare systems and policies in the Nordic countries and China. In P. Kettunen, S. Kuhnle \& R. Yuan (Eds.), Reshaping welfare institutions and policies - China and the Nordic Countries (pp. 13-29). Helsinki: NordWel.

Kuivalainen, S. \& Nelson, K. (2012). Eroding minimum income protection in the Nordic countries? Reassessing the Nordic model of social assistance. In J. Kvist, J. Fritzell, B. Hvinden \& O. Kangas (Eds.), Changing social equality. The Nordic welfare model in the $21^{\text {st }}$ century (pp. 69-88). Bristol: The Policy Press.

Lee, Y. \& Ku, Y. (2007). East Asian welfare regimes: testing the hypothesis of the developmental welfare state. Social Policy \& Administration, 41(2), 197-212.

Lei, J. (2012). China's welfare regime 1949-2011: the key role of the Communist Party of China. Sheffield: The University of Sheffield. 
Lei, J. \& Walker, A (2014). The Big Society in China: a failed experiment. Social Policy and Society, 2(1), 17-30.

Leung, J. C.B. (2005). Social welfare in China. In A. Walker \& C. Wong (Eds.), East Asian welfare regimes in transition. From Confucianism to globalization. Bristol: The Policy Press.

Lin, K. (2001). Chinese perceptions of the Scandinavian social policy model. Social Policy \& Administration, 35(3), 321-340.

Liu, J. (2011). Life goes on: redundant women workers in Nanjing. In B. Carrillo \& J. Duckett (Eds.), China's changing welfare mix (pp. 82-103). Abingdon, UK: Routledge.

Liu, H. \& Kongshøj, K. (2014). Chinas welfare reform: an ambiguous road towards a social protection floor. Global Social Policy, 14(3), 352-368. doi:10.1177/1468018113513914

Manning, N. (2011). The reform of health policy in China - left behind in the race to industrialize? Social Policy \& Administration, 45(6), 649-661.

Ministry of Employment and the Economy. (2012). Labor market reforms and performance in Denmark, Germany, Sweden and Finland. Helsinki: Ministry of Employment and the Economy.

Ministry of Civil Affairs of the People's Republic of China. (2013). Urban minimum allowance statistics, Ministry of Civil Affairs of the People's Republic of China. Retrieved August 1, 2013, from http://dbs.mca.gov.cn/article/csdb/tjsj/

Murphy, R. \& Tao, R. (2007). No wage and no land: new forms of unemployment in rural China. In G. Lee and M. Warner (Eds.), Unemployment in China: Economy, human resources and labor markets (pp. 128-148). Abingdon, UK: Routledge.

The National Labour Market Authority. (2012). Arbejdsløshedsdagpenge. Retrieved July 12, 2013, from http://www.ams.dk/Borgerservice/Arbejdsloeshedsdagpenge.aspx

National Bureau of Statistics of China. (2013). China Statistical Yearbook 2012, Beijing: National Bureau of Statistics of China.

Ngok, K. (2013). Shaping social policy in the reform era in China. In M. Izuhara (Ed.), Handbook on East Asian social policy. Cheltenham: Edward Elgar.

Nososco. (2012). Social Protection in the Nordic Countries 2009/10. Copenhagen: NOSOSCO. 
Pfeifer, M. (2012). Comparing unemployment protection and social assistance in 14 European countries. Four worlds of protection for people of working age. International Journal of Social Welfare, 21(1), 13-15.

OECD (2010). Net Replacement Rates for Six Family Types: Initial Phase of Unemployment, OECD. Retrieved February 23, 2014, from http://www.oecd.org/els/benefitsandwagesstatistics.htm

Pelkonen, A. (2008). Reconsidering the Finnish model - information society policy and modes of governance. Trames, 12(62), 400-420.

Petersen, K. \& Åmark, K. (2006). Old Age Pensions in the Nordic Countries, 1880-2000. In N. F. Christensen, K. Petersen, N. Edling \& P. Haave (Eds.), The Nordic Model of Welfare. A Historical Reappraisal (pp. 145188). Copenhagen: Museum Tusculanum Press.

Scruggs L. \& Allan, J. (2006). The material consequences of welfare states benefit generosity and absolute poverty in 16 OECD Countries. Comparative Political Studies, 39(7), 880-904.

Sjöberg, O. (2011). Sweden: ambivalent adjustment. In J. Clasen \& D. Clegg (Eds.), Regulating the risk of unemployment: National adaptions to post-industrial labor markets in Europe (pp. 208-232). Oxford: Oxford University Press.

Solinger, D. J. (2011). Dibaohu in distress: the meagre minimum livelihood guarantee system in Wuhan. In B. Carrillo \& J. Duckett (Eds.), China's Changing Welfare Mix (pp. 36-63). Abingdon: Routledge.

Statistics Denmark (2013). Work, Wage and Income (wage index for private, municipal and state sector), Retrieved July 14, 2013, from http://www.statistikbanken.dk/statbank5a/default.asp?w=1680

Torp, H. (1999). Dagpengesystemene i Norden og tilpasning på arbeidsmarkedet [Unemployment-insurance systems in the Nordic countries and adaptations in the labour market] (Vol. 1999:572, TemaNord (online)). Copenhagen: Nordisk Ministerråd.

UNECE (United Nations Economic Commission for Europe) Statistical Database. (2013): Gross Average Monthly Wages by Country and Year. Retrieved June 22, 2013, from http://w3.unece.org/pxweb/dialog/varval.asp?ma=60_MECCWagesY_r \&path=../database/STAT/20-ME/3MELF/\&lang=1\&ti=Gross+Average+Monthly+Wages+by+Country+and +Year 
Venn, D. (2012). Eligibility criteria for unemployment benefits: quantitative indicators for OECD and EU countries. Paris: OECD Social, Employment and Migration Working Articles.

Vodopivec, M. \& Tong, M. H. (2008). China: improving unemployment insurance. Social protection \& labor discussion article. Washington: The World Bank.

Webber, M. \& Ying, Z. (2007). Primitive accumulation, transition and unemployment in China. In G. Lee \& M. Warner (Eds.), Unemployment in China: economy, human resources and labor markets (pp. 17-35). Abingdon, UK: Routledge.

Walker, A. \& Wong, C. (2005). Introduction: East Asian welfare regimes. In A. Walker \& C. Wong (eds.), East Asian welfare regimes in transition. From Confucianism to globalization (pp. 3-20). Bristol: The Policy Press.

Warner, M. \& Lee, G. (2007). Setting the scene. Unemployment in China. In G. Lee \& M. Warner (Eds.), Unemployment in China: Economy, Human Resources and Labor Markets (pp. 3-16). Abingdon: Routledge

Wong, L. (2013). From Apartheid to Semi-Citizenship: Chinese Migrant Workers and their Challenge to Social Policy. In M. Izuhara (Ed.), Handbook on East Asian Social Policy (pp. 416-433). Cheltenham: Edward Elgar.

Xu, F. (2012). Looking for work in post-socialist China. Oxon: Routledge.

Zhang, H. (2012). Discourse change and policy development in social assistance in China. International Journal of Social Welfare, 21(4), 433-442.

Zhang, J. (2013). Origins, developments and transformations of the idea of the Nordic model - a social policy perspective. Chinese Journal of European Studies, 31(2), 105-119 (In Chinese). 